\title{
Wind Technology Application
}

\section{Wind Powering America engages in technology market acceptance, barrier reduction, and technology deployment support activities}

When the U.S. Department of Energy (DOE) launched the Wind Powering America (WPA) initiative in 2000, there were 2,500 megawatts (MW) of installed wind capacity in the United States. By September 2010, the U.S. installed capacity exceeded $36,000 \mathrm{MW}$. Twenty-six states now have more than $100 \mathrm{MW}$ installed, and nine states have more than 1,000 MW installed. The Wind Powering America (WPA) team at NREL's National Wind Technology Center works to increase the level of technology market acceptance and reduce barriers to appropriate wind energy deployment, primarily by focusing on six program areas: workforce development, communications and outreach, stakeholder analysis and resource assessment, wind technology technical support, wind power for Native Americans, and federal sector support and collaboration.

\section{Workforce Development}

The nation's potential to capitalize on a new international green energy economy and to take advantage of the extensive national wind resource will hinge partially on the development of a highly trained and capable wind workforce. Although a few U.S. higher education institutions offer wind technology education programs and community and technical colleges provide job skills training, there is a shortage of programs to prepare highly skilled graduates for the wide diversity of wind industry careers. WPA has conducted extensive activities to address this barrier, including developing a wind workforce development roadmap, conducting technologyspecific training activities, supporting the identification of job classifications, and developing wind energy curricula at all levels.

One of the key WPA education activities is the Wind for Schools project. The National Renewable Energy Laboratory initiated the Wind for Schools project in 11 states and supports other states or schools interested in implementing similar projects through an affiliate program. The project's objectives are to 1) educate college students in wind energy applications, which will equip engineers for the growing U.S. wind industry; 2 ) engage K-12 teachers and students in wind energy, sparking the interest of the next generation to enter science, engineering, and the energy field; and 3 ) introduce wind energy to rural communities, initiating a

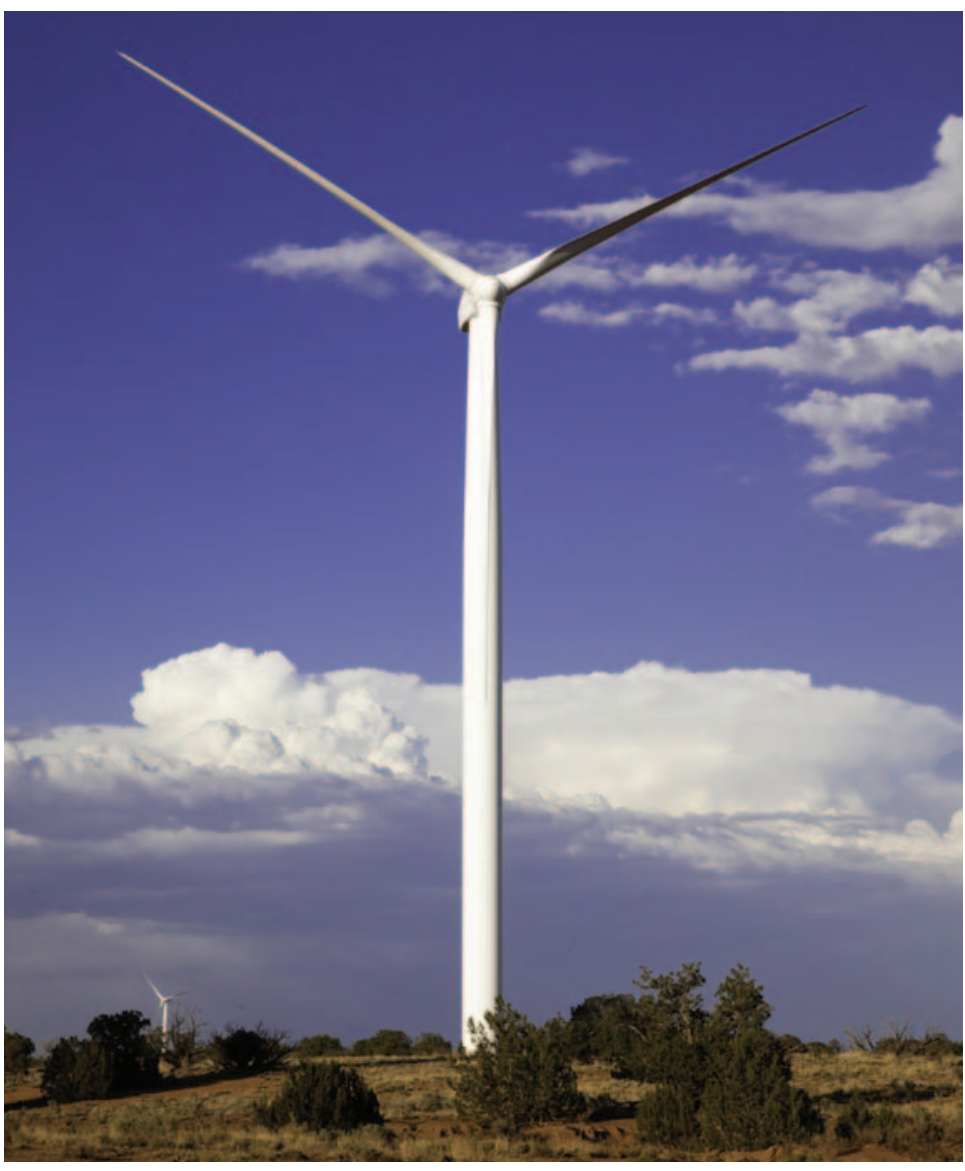

A Wind Powering America anemometer loan led to Arizona's first utility-scale wind project, the 63-MW Dry Lake Wind Power Project near Holbrook that came online in 2009.

discussion of wind energy's benefits and challenges. Through this activity, Wind Application Centers in higher education institutions develop and implement wind energy curricula. College students participate as "consultants in training," while performing all of the steps to install small wind systems at interested K-12 host schools. The project provides curricula, teacher-training workshops, and integrated data systems so that schools and universities can serve as "living laboratories" for the students (even at schools without access to a viable wind resource).

\section{Communications and Outreach}

WPA helps to coordinate and support a network of more than 33 state wind working groups and many regional partners that form strategic alliances to communicate the benefits and challenges of wind energy to state, regional, and national stakeholders.

To further educate U.S. stakeholders about the benefits of wind energy development, the WPA team works with a huge host of stakeholders including state energy officials, rural community 
leaders, landowners, agricultural-sector representatives, county commissioners, and rural-development specialists. WPA staff disseminates accurate and needed information while building and supporting a diverse partner network to educate, engage, and enable critical stakeholders to make informed decisions about how wind energy contributes to the U.S. electricity supply. To support these efforts, WPA staff work to identify key stakeholder groups, develop effective and targeted communications strategies, capture and disseminate success stories and lessons learned from around the nation while providing objective, third-party information on stakeholder concerns.

\section{Stakeholder Analysis and Resource Assessment}

Providing objective information on the benefits and impacts of wind technology deployment is a critical element of WPA activities. One of the main stakeholder analysis tools developed by WPA is the Jobs and Economic Development Impacts (JEDI) model. This user-friendly tool was developed to estimate the jobs and economic impacts of constructing and operating local wind farms. JEDI models are used by county and state decision-makers, public utility commissions, potential project owners, and others interested in the economic impacts from new electricity generation projects. The model allows a clear and easy comparison of the economic impacts of different energy options.

In addition, the WPA team supports resource assessment research including a collaborative effort between NREL and AWS Truepower to update the U.S. wind potential maps for the first time in almost two decades. New wind energy potential estimates at $80 \mathrm{~m}$ and $100 \mathrm{~m}$ heights have been completed. These assessments and the resulting maps offer new understanding of the U.S. wind energy potential.

\section{Wind Technology Technical Support}

Wind technologies can be used in many applications. The WPA team works to provide information and answer questions like, "Can I use wind energy to power my home, farm, or business?" or "What are the regulatory barriers to the deployment of offshore

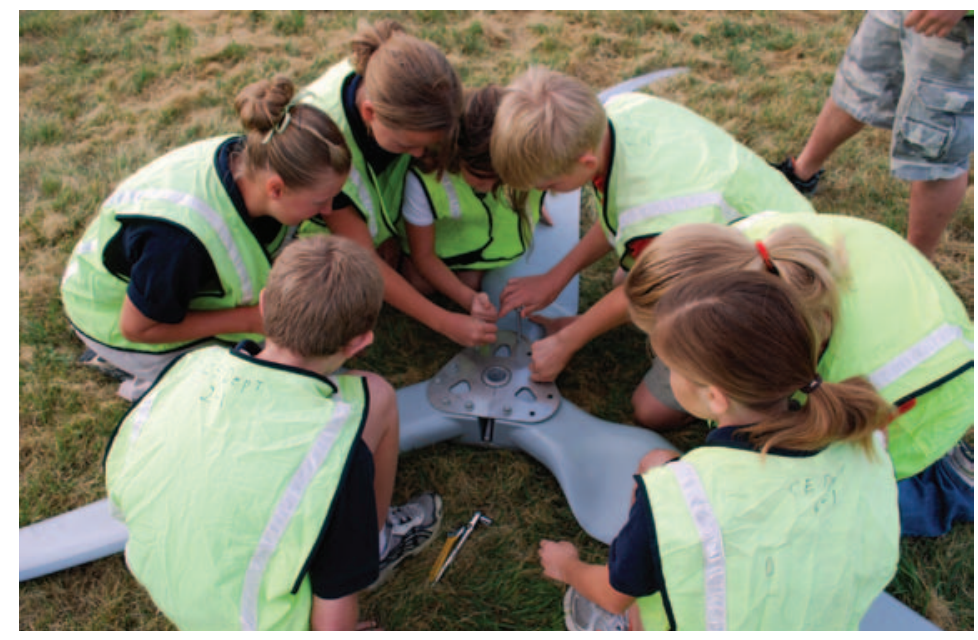

Students at Pocatello Community Charter School in Idaho participated in WPA's Wind for Schools project. The public attended a turbine dedication and ribbon-cutting ceremony at the school to celebrate "Pocatello's first wind turbine." wind technologies?" As more people across the country seek affordable, reliable, and environmentally-conscious electricity sources, the need for accurate information on different technology options increases. The WPA team at NREL produces applicationspecific information such as a series of small wind consumer's guides and other outreach materials to educate consumers about the benefits of wind technologies.

\section{Wind Power for Native Americans}

The United States is home to more than 700 Native American tribes located on 96 million acres, and much of this land enjoys excellent wind resources that could be commercially developed to provide electricity and revenue to the reservations. To support the development of Native American wind resources, WPA provides technical assistance and outreach activities to more than 50 tribes from 20 states, including an anemometer (a device that measures wind) loan program, pre-feasibility studies, and semi-annual workshops, in collaboration with DOE's Tribal Energy Program.

\section{Federal Sector Support and Collaboration}

The WPA team at the NWTC works to support the deployment of wind projects and wind-related energy assessments, primarily supporting and collaborating with federal agencies, states, and international governments. These activities include direct technical assistance on wind project siting, permitting, and environmental issues on specific projects, allowing agencies or tribal nations to meet directives associated with renewable energy generation. WPA staff also provides educational support to agencies or organizations responsible for the stewardship of public lands. Finally, the program works collaboratively in the development of national, state, or regional energy assessments, supporting wind-focused deployment activities in states, U.S. territories, and protectorates.

For more information, contact 303-384-6900.

\section{Helpful Web Sites}

Wind Powering America

www.windpoweringamerica.gov

The National Wind Technology Center

www.nrel.gov/wind

Department of Energy Wind and Water Power Program

www1.eere.energy.gov/windandhydro

National Renewable Energy Laboratory

1617 Cole Boulevard, Golden, Colorado 80401 • 303-275-3000 • www.nrel.gov

NREL is a national laboratory of the U.S. Department of Energy

Office of Energy Efficiency and Renewable Energy

Operated by the Alliance for Sustainable Energy, LLC

NREL/FS-5000-45728 • December 2010

Printed with a renewable-source ink on paper containing at least $50 \%$ wastepaper, including $10 \%$ post consumer waste.

Photo credits for page 1 masthead: PIX15758, PIX15005, PIX12415, and PIX14691. Front page: PIX16705; back page: PIX16749. 